\title{
Effect of Nitrogen Rates on Dry Matter Cumulation and Nitrogen Partition of Wheat Plants Under Different Planting Methods
}

\author{
M.E. El-Temsah ${ }^{\#}$ \\ Agronomy Department, Faculty of Agriculture, Ain Shams University, Cairo, Egypt.
}

\begin{abstract}
T WO FIELD trials were conducted at the Agricultural Experiment Station, Faculty of Agriculture Ain Shams University, Kalubia, Egypt during 2013/2014 and 2014/2015 growing seasons to investigate the response of wheat to nitrogen fertilizer rates under different planting methods. Each experiment contained twelve treatments which were the combination of four planting methods (Broadcasting (conventional tilled flat method), rows (20 cm apart), ridge (ridge width $60 \mathrm{~cm}$ ) and bed (bed width $120 \mathrm{~cm})$ ) and three nitrogen fertilizer rates $(60,80$ and $100 \mathrm{~kg}$ Nitrogen/fad (faddan $=4200 \mathrm{~m}^{2}$ ). Design of experiments was split plot design with three replications, where planting methods in the main plot and nitrogen rates in the sub plots. Data revealed that planting methods and nitrogen rats were significant affected on dry weight of wheat plant organs. Leaves; tillers and spikes dry weight $\left(\mathrm{g} / \mathrm{m}^{2}\right)$ were markedly increased with increasing nitrogen rates $(60,80$ and $100 \mathrm{~kg} \mathrm{~N} / \mathrm{fad})$. Weight of leaves was markedly decreased by progressing plants towards maturity. On the other hand, N use efficiency (NUE) and nitrogen physiological efficiency (NPE) exhibiting maximum values, they were $42.68 \mathrm{~kg}$ grains $/ \mathrm{kg}$ applied nitrogen and $43.45 \mathrm{~kg}$ grains $/ \mathrm{kg}$ of $\mathrm{N}$ absorbed, respectively when plants were fertilized with 60 $\mathrm{kg} \mathrm{N} /$ fad followed by adding 80 and $100 \mathrm{~kg} \mathrm{~N} /$ fad. Planting wheat on bed exhibited statistically maximum leaves, tillers and spikes dry weight $\left(\mathrm{g} / \mathrm{m}^{2}\right)$ in comparable to the other plant methods during phenological stages of wheat growth. Planting wheat on bed exhibiting maximum nitrogen use efficiency (42.50 kg grains/kg N applied) and nitrogen physiological efficiency $(43.28 \mathrm{~kg}$ grains/kg N absorbed). Grain nitrogen yield (GNY), straw nitrogen yield (SNY) and total nitrogen yield (TNY), were increased by increasing nitrogen rates up to $100 \mathrm{~kg} \mathrm{~N} / \mathrm{fad}$ under sowing methods treatment. Meanwhile 60 or $80 \mathrm{~kg} \mathrm{~N} /$ fad exhibited maximum values of NUE and N recovery efficiency (NRE) under sowing on ridge or on bed.
\end{abstract}

Keywords: Triticum aestivum, Wheat, Planting methods, Nitrogen rates, Dry matter accumulation, Nitrogen partitioning efficiency.

\section{Introduction}

Wheat is the major and essential crop in Egypt. It grows in Egypt on an area of 3.39 million faddan (faddan $=4200 \mathrm{~m}^{2}$ ) with an annual production of about 9.28 million tones and with an average yield of 2.74 tons per faddan during 2014-2015 growing season (CLAC, 2015).

Planting method has an important role, suitable seed depth achieves better germination and subsequent yield. Planting wheat with different methods depends on available soil water, planting date and available planting machine. It's planted through broadcasting on a large area, although it requires high seed rate and results low yield. While planting wheat in drill is a recommended method due to uniform seed distribution at suitable depth and usually gave high yield. Planting wheat in line gave maximum grain yield compared with different planting methods (Fenech \& Papy, 1977; Singh \& Singh, 1992; Singh et al., 1994; Galichenko, 1994 and Kilic, 2010).

Wheat sowing on beds has an easy control of weeds by mechanical means, as well as, increases water use efficiency and nitrogen use efficiency. Planting on beds and lines facilitates the irrigation process and applied of fertilizer and found that the appropriate methods of agriculture, especially on

\#Corresponding author email: dreltemsah@agr.asu.edu.eg 
beds, which increase the fertilizers use efficiency and water distribution, also reduce the incidence of weeds and reduce the rate of seeds with increasing grain yield (Hobbs et al., 2000 and El-Hadidi et al., 2015). Planting wheat on narrow beds gave similar leaf area index to that traditional planting method, while planting in wider beds produced less leaf area index than that in traditional planting method (Mollah et al., 2015).

Under ideal conditions, nitrogen availability is one of the most critical variable factors and because of deficiency in the available nitrogen and organic matter; therefore farmers tend to apply nitrogen in excess amount over the requirements (El-habbal et al., 2008). By increasing nitrogen fertilization, the wheat crop is increasing, but the excessive increasing is working on groundwater pollution (Semenov et al., 2007). The use of high levels of nitrogen fertilization makes wheat plants express their production capacity, this requires determining the optimal rate of nitrogen fertilization in order to reduce the losses during the growth of the crop and avoid pollution of groundwater and its harmful impact on the environment and human health. Nitrogen and phosphorus from chemical fertilizers, individually but especially while interacting, contribute to the accumulation of protein and gluten in wheat caryopsis (Agapie et al., 2016).

Nitrogen use efficiency is grain yield $\mathrm{kg} / \mathrm{kg}$ of available nitrogen. It is difficult to measure available nitrogen and total nitrogen in the plant, therefore it is replaced by measuring the added nitrogen to soil and the absorbed nitrogen in the vegetative parts, respectively. As well, nitrogen use efficiency can be divided into components of absorbed nitrogen efficiency and nitrogen physiological efficiency. These two components are expressed nitrogen use efficiency (Moll et al., 1982; Dawson et al., 2008 and Haile et al., 2012). This investigated aim to detect the performance of wheat at different nitrogen fertilizer levels under different sowing methods.

\section{Materials and Methods}

Two field experiments were carried out in Agric. Expt. Farm at Shalakan, Kaleobia Governorate, Cairo, Egypt during 2013/2014 and $2014 / 2015$ growing seasons to study the response of bread wheat (Triticum aestivum L.) cultivar Sids 12 to nitrogen fertilizer under different planting methods. Each experiment included 12 treatments which were the combination between three nitrogen fertilizer rates $(60,80$ and $100 \mathrm{~kg}$ Nitrogen/ fad) and four planting methods at the seed rate of $50 \mathrm{~kg} / \mathrm{fad}$. Plant methods included, broadcasting (conventional tilled flat method), rows (grains were drilled in a dig long narrow furrow $20 \mathrm{~cm}$ apart rows), ridge (grain were drilled on three dig long narrow furrows on ridge (ridge wide $60 \mathrm{~cm}$ )) and raised bed (grain were drilled on six dig long narrow furrows on bed (bed side $120 \mathrm{~cm}$ )). The experimental design used was split plot design in 3 replications. The planting methods were arranged in the main plot and nitrogen fertilizers were allocated in the sub plots. The experimental unit area (plot area) was $3.6 \times 4 \mathrm{~m}\left(14.4 \mathrm{~m}^{2}\right)$.

The mineral nitrogen fertilizer was applied as ammonium nitrate $(33.5 \% \mathrm{~N})$. The $\mathrm{N}$ fertilizer was added in two equal portions. The first portion was added just before the first irrigation, and the second portion was added just before the second irrigation. All recommended agronomic practices were uniformly applied to all of the experimental units.

\section{Data recorded}

\section{Dry matter partitioning}

At the different stages of growth, sample of $0.06 \mathrm{~m}^{2}$ was chosen at random from every treatment in three replications at booting, heading and physiological maturity to determine dry weight of tillers, leaves and spikes by drying the samples in an oven at $105^{\circ} \mathrm{C}$ to constant weight to estimate dry matter partitioned to tillers, leaves, spikes and biomass ( $\%$ of total plant biomass).

\section{Nitrogen physiological parameters}

The accumulated total nitrogen in grains and straw yields were estimated using microKjeldahl apparatus according to AOAC (1995) to calculate nitrogen physiological parameters including nitrogen recovery efficiency $(\mathrm{NRE}=$ $\mathrm{kg} \mathrm{N}$ absorbed*100/kg $\mathrm{N}$ applied/fad), nitrogen use efficiency (NUE = grain yield in $\mathrm{kg} / \mathrm{fad} / \mathrm{N}$ applied $\mathrm{kg} / \mathrm{fad}$ ), nitrogen harvest index (NHI = total $\mathrm{N}$ in grains $* 100 /$ total $\mathrm{N}$ uptake) and nitrogen physiological efficiency (NPE = grain yield in $\mathrm{kg}$ / fad / $\mathrm{N}$ absorbed $\mathrm{kg} /$ fad) were calculated according to Timsina et al (2001). The mechanical and chemical analyses of the experimental soil were estimated according to Black (1965) and Jackson (1967). Mechanical and chemical analysis of the experimental soil are presented in Table 1. 
TABLE 1. Soil mechanical and chemical analyses of experimental farm during 2013 / 2014 and 2014 / 2015 seasons.

\begin{tabular}{lclc}
\hline Mechanical analysis & Average & Chemical analysis & Average \\
\hline Sand \% & 16 & $\mathrm{pH}$ & 7.3 \\
Silt \% & 29 & EC $(\mathrm{dS} / \mathrm{m})$ & 1.1 \\
Clay \% & 55 & Organic Mater \% & 1.81 \\
Soil texture & Clay loam & Nutrients $(\mathrm{mg} / \mathrm{kg}$ soil $)$ & 1200 \\
& & Total N & 95 \\
& & $\mathrm{P}$ & 12.7 \\
\hline
\end{tabular}

Statistical analysis

The obtained data were computed for proper statistical analysis according to SAS Program (2003). The LSR at 5\% level of significance was used to differentiate between means. Data of 2013/2014 and 2014/2015 growing seasons were subjected to homogeneity variance test for running the combined analysis of the data.

\section{Results and Discussion}

\section{Effect of nitrogen fertilizers}

Dry matter partitioning

Dry weight of wheat vegetative parts under different nitrogen fertilizers including leaves and tillers at booting stage in addition to leaves, tillers and spikes at heading stage and physiological maturity were studied at phenological stages. Data in Table 2 cleared that leaves, tillers and spikes dry weight were markedly varied, being in increasing order with different nitrogen rates 60 , 80 and $100 \mathrm{~kg} \mathrm{~N} / \mathrm{fad}$. The weight of leaves was markedly decreased by progressing plants towards maturity. These decreases were associated with increasing spikes dry weight up to physiological maturity. This could be due to the transmission of photosynthetic products from the vegetative parts to fruit parts, in accordance with Temsina et al. (2001) and El-Habbal et al. (2008).

Table 3 cleared that the distribution percentage of vegetative parts of wheat (leaves, tillers and spikes) were significantly varied versus phenological stages under different nitrogen rates. The percentages of leaves scored the highest values at booting stage as compared with heading stage and physiological maturity stage. Nitrogen rate $60 \mathrm{~kg} \mathrm{~N} /$ fad exhibited statistically maximum percentages of leaves under all phenological stages followed by $100 \mathrm{~kg}$ nitrogen rate fertilizer and $80 \mathrm{~kg}$ nitrogen fertilizer rate/ fad. As the plants progress towards maturity, the distribution ratio decreases significantly. The decline accompanied with increase of spikes \% ranging from 38.52 for $60 \mathrm{~kg} \mathrm{~N} /$ fad to $40.69 \%$ for $80 \mathrm{~kg} \mathrm{~N} /$ fad of total plant dry weight.

\section{Nitrogen physiological efficiency}

Data of grain nitrogen yield (GNY), straw nitrogen yield (SNY) and total nitrogen yield (TNY), nitrogen use efficiency (NUE), nitrogen recovery efficiency (NRE), nitrogen physiological efficiency (NPE) and nitrogen harvest index (NHI) traits were differed greatly depending on the nitrogen fertilizers. Table 4 shows that GNY, SNY and TNY were increased by increasing nitrogen rates up to $100 \mathrm{~kg} \mathrm{~N} /$ fad. On the other hand, NUE and NPE reached maximum values $42.68 \mathrm{~kg}$ grains $/ \mathrm{kg}$ nitrogen applied and $43.45 \mathrm{~kg}$ grains $/ \mathrm{kg} \mathrm{N}$ absorbed, respectively when plants fertilized by $60 \mathrm{~kg} \mathrm{~N} /$ fad followed by fertilizing with 80 and $100 \mathrm{~kg} \mathrm{~N} /$ fad. While, NRE\% highest values (99.93 and 98.62\%) recorded with $80 \mathrm{~kg} \mathrm{~N} /$ fad. and $60 \mathrm{~kg} \mathrm{~N} / \mathrm{fad}$, followed by $100 \mathrm{~kg} \mathrm{~N} / \mathrm{fad}$. As for nitrogen harvest index, the data in Table 4 finding slight differences with studying nitrogen rates to be ranged between 85.28 to $85.77 \%$. These results are similar with that obtained by Tahir et al. (2005) and Haile et al. (2012).

\section{Effect of planting methods}

Dry matter partitioning

Dry weight of wheat vegetative parts with different plant methods was measured at different phenological stages. Table 5, showed significant differences were recorded in dry weight of vegetative parts. Planting on bed scored statistically highest leaves, tillers and spikes dry weight in comparison with the other plant methods followed by planting on ridge, drill and broadcasting during phenological stages of wheat growth. These results are in an agreement with Kilic (2010). 

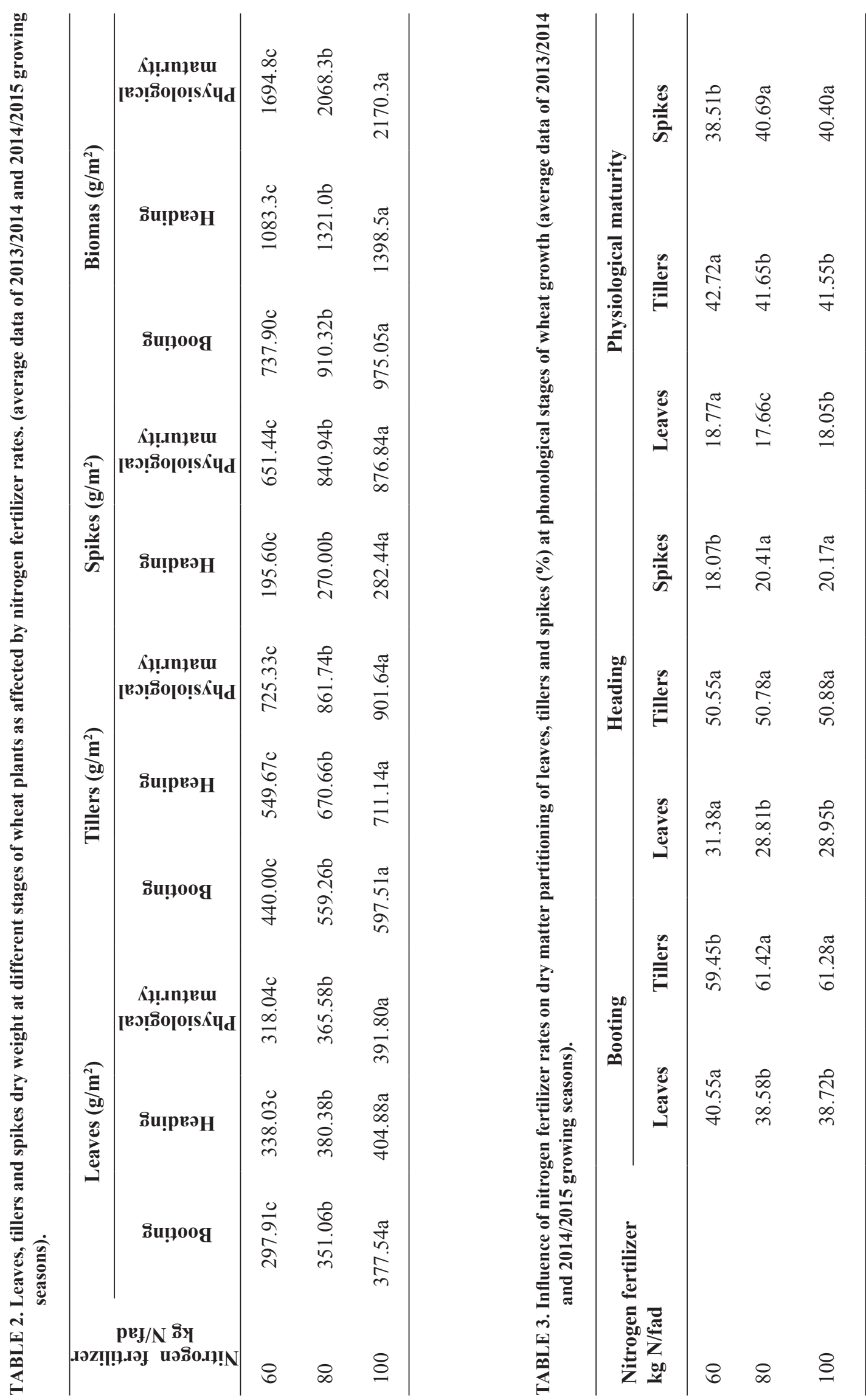

Egypt.J.Agron. Vol. 39, No.3 (2017) 


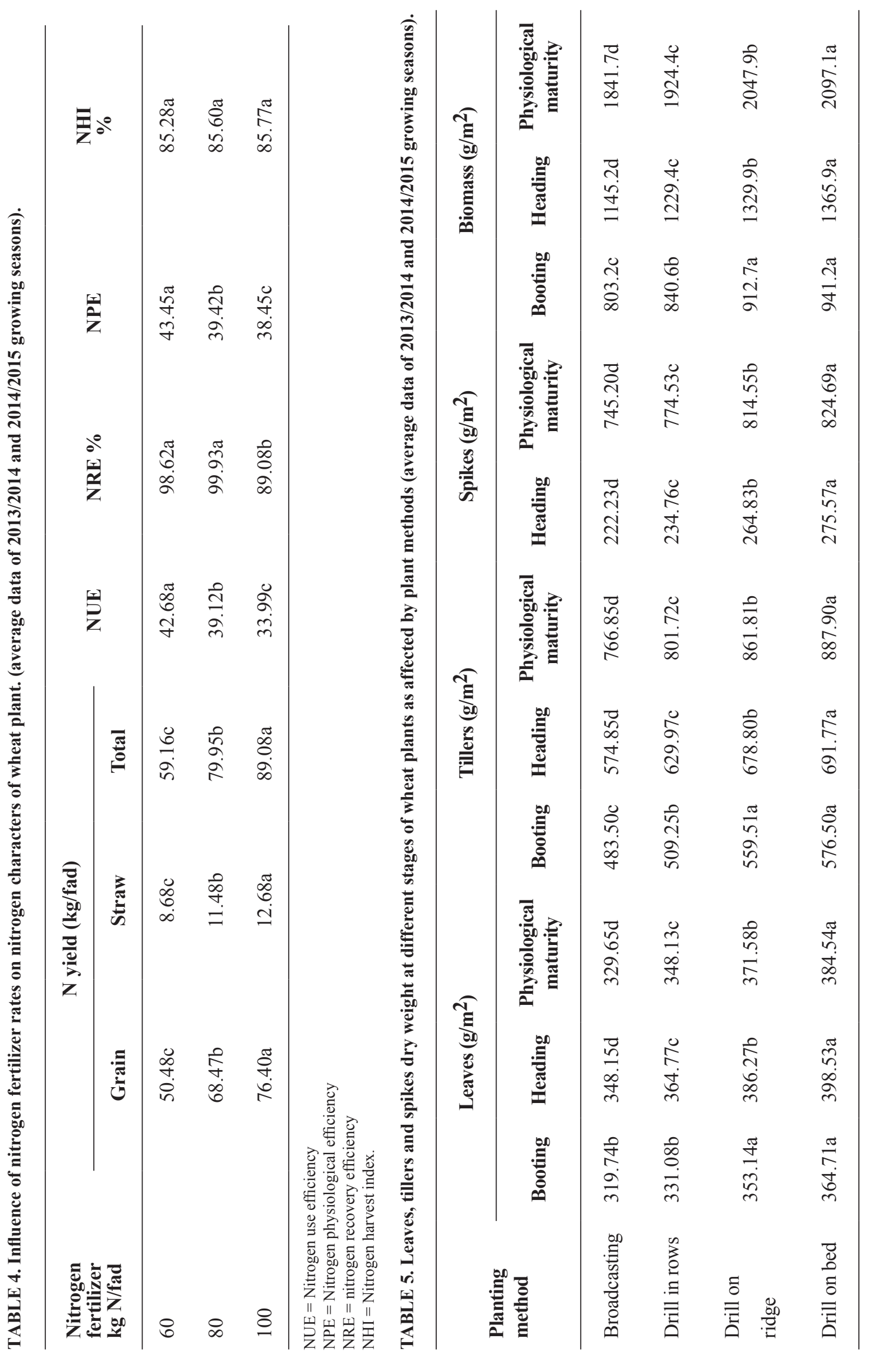

Egypt.J.Agron. Vol. 39, No.3 (2017) 
Furthermore, Table 6 shows a different trend in the percentage of dry matter partitioning expressed from the total dry weight of plant. Sowing wheat grains at broadcasting achieved the highest significant ratio of leaves at booting and heading stages while, the highest significant ratio of leaves at physiological maturity was obtained by planting wheat on bed. On the contrary, the highest percentages of tillers at booting, heading and physiological maturity were obtained by sowing wheat plants on ridge, drill sowing and on bed, respectively. While, the highest spikes percentages at heading and physiological maturity were obtained by sowing wheat plants on bed and broadcasting, respectively. A decrease in the percentage of leaves and tillers was observed through progress of the plants towards maturity.

\section{Nitrogen physiological parameters}

Data in Table 7 showed that planting wheat on bed exhibited the highest values of nitrogen use efficiency $(42.50 \mathrm{~kg}$ grains $/ \mathrm{kg} \mathrm{N}$ applied) and nitrogen physiological efficiency (43.28 $\mathrm{kg}$ grains $/ \mathrm{kg} \mathrm{N}$ absorbed). While, the highest values of nitrogen recovery efficiency (99.85) were obtained by wheat plants sowing on ridge. Concerning grain nitrogen yield, straw nitrogen yield, total nitrogen yield and nitrogen harvest index, the data in Table 7 find slight differences among the studied planting methods.

Effect of the interaction between nitrogen fertilizers and planting methods

\section{Dry matter partitioning}

The interaction between nitrogen fertilizers and planting methods affected significantly in dry weight of above ground vegetative organs which was measured at different stages as found in Table 8. Data in Table 8 cleared that dry weight of leaves and tillers were clearly decreased by progressing plants towards maturity. These decreases were associated with increasing of spikes dry weight up to physiological maturity. Dry weight of above ground vegetative organs was evaluated at different phenological stages were increased by increasing nitrogen rates up to $100 \mathrm{~kg} \mathrm{~N} /$ fad under studied different sowing methods. On the other hand nitrogen rates 80 and $100 \mathrm{~kg} \mathrm{~N} /$ fad showed slight differences versus studying dry weight of above ground vegetative organs was measured at different phenological stages. Cultivation of wheat on beds leads to easily mechanical weed control and increased nitrogen and water use efficiency (Hobbs et al., 2000 and El-Hadidi et al., 2015).

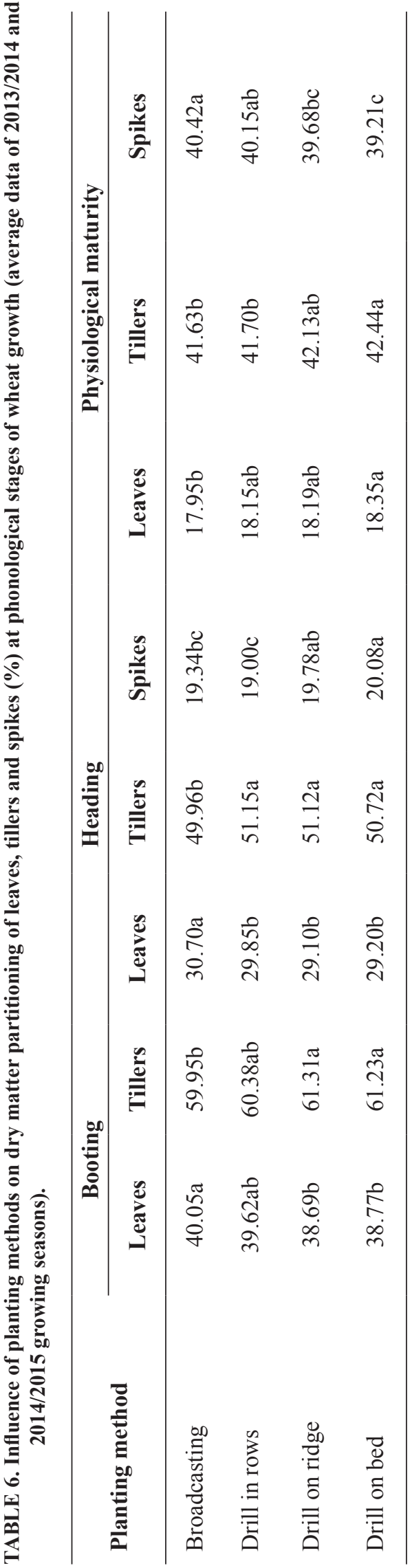

Egypt.J.Agron. Vol. 39, No.3 (2017) 

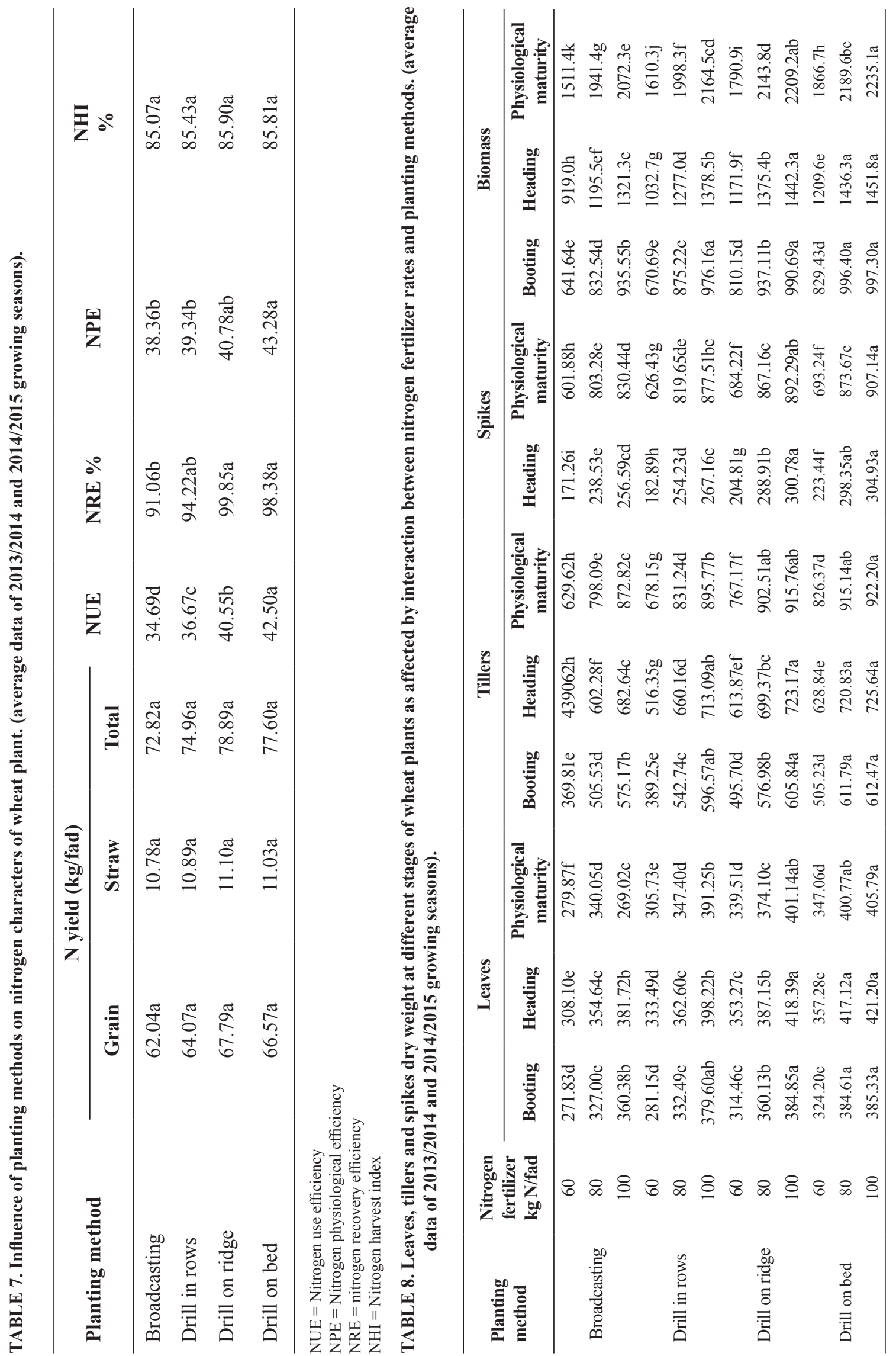

Egypt.J.Agron. Vol. 39, No.3 (2017) 
Furthermore, Table 9 shows a different trend in the percentage of dry matter partitioning expressed from the total dry weight of plant. The maximum percentage of leaves showed when wheat plant fertilized by $60 \mathrm{~kg} \mathrm{~N} /$ fad with broadcasting or drill sowing, during booting and heading stages while, maximum percentage of leaves during physiological maturity stage was recorded when wheat plant treated with $60 \mathrm{~kg} \mathrm{~N} /$ fad with all studied planting methods. While the highest percentage of spikes marked when wheat plant fertilized by 80 or $100 \mathrm{~kg} \mathrm{~N} /$ fad with ridge or bed sowing method and $80 \mathrm{~kg} \mathrm{~N} /$ fad with broadcasting or drill sowing method at heading and physiological maturity.

TABLE 9. Influence of interaction between nitrogen fertilizer rates and planting methods on dry matter partitioning of leaves, tillers and spikes (\%) at phonological stages of wheat growth (average data of 2013/2014 and 2014/2015 growing seasons).

\begin{tabular}{|c|c|c|c|c|c|c|c|c|c|}
\hline \multirow{2}{*}{$\begin{array}{l}\text { Planting } \\
\text { method }\end{array}$} & \multirow{2}{*}{$\begin{array}{l}\text { Nitrogen } \\
\text { fertilizer } \\
\mathrm{kg} \mathrm{N} / \text { fad }\end{array}$} & \multicolumn{2}{|c|}{ Booting } & \multicolumn{3}{|c|}{ Heading } & \multicolumn{3}{|c|}{ Physiological maturity } \\
\hline & & Leaves & Tillers & Leaves & Tillers & Spikes & Leaves & Tillers & Spikes \\
\hline \multirow{3}{*}{ Broadcasting } & 60 & $42.38 \mathrm{a}$ & $57.62 b$ & $33.53 \mathrm{a}$ & $47.83 \mathrm{e}$ & $18.64 \mathrm{c}$ & $18.52 \mathrm{ab}$ & $41.66 \mathrm{cde}$ & $39.82 \mathrm{c}$ \\
\hline & 80 & $39.26 b$ & $60.74 \mathrm{a}$ & $29.67 \mathrm{bc}$ & $50.38 \mathrm{~cd}$ & $19.95 b$ & $17.52 \mathrm{de}$ & $41,11 \mathrm{f}$ & $41.37 \mathrm{a}$ \\
\hline & 100 & $38.51 b$ & $61.49 \mathrm{a}$ & $28.89 \mathrm{bcd}$ & $51.67 \mathrm{abc}$ & $19.44 b$ & $17.81 \mathrm{cde}$ & $42.12 \mathrm{c}$ & $40.07 \mathrm{c}$ \\
\hline \multirow{3}{*}{ Drill in rows } & 60 & $41.94 \mathrm{a}$ & $58.06 \mathrm{~b}$ & $32.29 \mathrm{a}$ & $50.00 \mathrm{~d}$ & $17.71 d$ & $18.99 \mathrm{a}$ & $42.11 \mathrm{c}$ & $38.90 \mathrm{~d}$ \\
\hline & 80 & $38.03 b$ & $61.97 \mathrm{a}$ & $28.39 \mathrm{~cd}$ & $51.70 \mathrm{abc}$ & $19.91 b$ & $17.39 \mathrm{e}$ & 41.60de & $41.01 \mathrm{ab}$ \\
\hline & 100 & $38.88 \mathrm{~b}$ & $61.12 \mathrm{a}$ & $28.89 \mathrm{bcd}$ & $51.73 \mathrm{ab}$ & $19.38 b$ & $18.07 \mathrm{bcd}$ & 41.38def & $40.55 \mathrm{bc}$ \\
\hline \multirow{3}{*}{ Drill on ridge } & 60 & $38.81 \mathrm{~b}$ & $61.19 \mathrm{a}$ & $30.15 b$ & $52.37 \mathrm{a}$ & $17.48 \mathrm{~d}$ & $18.96 \mathrm{a}$ & $42.84 b$ & $38.20 \mathrm{~d}$ \\
\hline & 80 & $38.42 b$ & $61.58 \mathrm{a}$ & $28.16 \mathrm{~d}$ & $50.84 \mathrm{bcd}$ & $21.00 \mathrm{a}$ & $17.45 \mathrm{e}$ & $42.10 \mathrm{c}$ & $40.44 b c$ \\
\hline & 100 & $38.85 b$ & $61.15 \mathrm{a}$ & $29.00 \mathrm{bcd}$ & $50.14 d$ & $20.86 a$ & $18.16 \mathrm{bc}$ & 41,46def & $40.38 \mathrm{bc}$ \\
\hline \multirow{3}{*}{ Drill on bed } & 60 & $39.09 \mathrm{~b}$ & $60.91 \mathrm{a}$ & $29.54 \mathrm{bcd}$ & $51.99 \mathrm{ab}$ & $18.47 \mathrm{c}$ & $18.60 \mathrm{ab}$ & $44.27 \mathrm{a}$ & $37.13 \mathrm{e}$ \\
\hline & 80 & $38.60 \mathrm{~b}$ & $61.40 \mathrm{a}$ & $29.04 \mathrm{bcd}$ & $50.19 d$ & $20.77 \mathrm{a}$ & $18.30 \mathrm{bc}$ & $41.80 \mathrm{~cd}$ & $39.90 \mathrm{c}$ \\
\hline & 100 & $38.62 b$ & $61.38 \mathrm{a}$ & $29.01 \mathrm{bcd}$ & $49.98 \mathrm{~d}$ & $21.01 \mathrm{a}$ & $18.15 b c$ & 41.26ef & $40.59 b c$ \\
\hline
\end{tabular}

Nitrogen physiological parameters

Interaction between nitrogen fertilizers and planting methods affected significantly on nitrogen physiological characters. Data in Table 10 showed that GNY, SNY and TNY were increased by increasing nitrogen rates up to $100 \mathrm{~kg} \mathrm{~N} / \mathrm{fad}$ under different sowing methods. Meanwhile 60 or $80 \mathrm{~kg} \mathrm{~N} /$ fad exhibited maximum values of NUE and NRE under sowing on ridge or on bed. The maximum value of NPE (45.97 kg grains/ $\mathrm{kg}$ nitrogen absorbed) was obtained when plants fertilized with $60 \mathrm{~kg} \mathrm{~N} /$ fad and sowing on bed, while nitrogen harvest index was not significant. 
TABLE 10. Influence of interaction between nitrogen fertilizer rates and planting methods on nitrogen characters of wheat plant (average data of 2013/2014 and 2014/2015 growing seasons).

\begin{tabular}{|c|c|c|c|c|c|c|c|c|}
\hline \multirow{2}{*}{$\begin{array}{l}\text { Planting } \\
\text { method }\end{array}$} & \multirow{2}{*}{$\begin{array}{l}\text { Nitrogen } \\
\text { fertilizer } \\
\mathrm{kg} \mathrm{N} / \text { fad }\end{array}$} & \multicolumn{3}{|c|}{$\mathrm{N}$ yield } & \multirow{2}{*}{ NUE } & \multirow{2}{*}{ NRE \% } & \multirow{2}{*}{ NPE } & \multirow{2}{*}{$\begin{array}{c}\text { NHI } \\
\%\end{array}$} \\
\hline & & Grain & Straw & Total & & & & \\
\hline \multirow{3}{*}{ Broadcasting } & 60 & $45.79 \mathrm{e}$ & $8.46 \mathrm{c}$ & $54.25 \mathrm{f}$ & $37.23 \mathrm{c}$ & $90.42 \mathrm{de}$ & $41.19 \mathrm{bcd}$ & $84.40 \mathrm{a}$ \\
\hline & 80 & $62.83 \mathrm{c}$ & $11.34 \mathrm{a}$ & $74.16 \mathrm{~d}$ & $34.24 \mathrm{def}$ & $92.71 \mathrm{de}$ & $37.33 \mathrm{e}$ & $84.72 \mathrm{a}$ \\
\hline & 100 & $77.51 \mathrm{a}$ & $12.54 \mathrm{a}$ & $90.04 \mathrm{a}$ & $32.54 \mathrm{f}$ & $90.04 \mathrm{de}$ & $36.56 \mathrm{e}$ & $86.09 \mathrm{a}$ \\
\hline \multirow{3}{*}{ Drill in rows } & 60 & $49.02 \mathrm{de}$ & $8.60 \mathrm{c}$ & $57.62 \mathrm{ef}$ & $40.74 b$ & $96.03 \mathrm{~cd}$ & $42.76 \mathrm{abc}$ & $85.09 \mathrm{a}$ \\
\hline & 80 & $66.10 \mathrm{bc}$ & $11.46 \mathrm{a}$ & $77.56 \mathrm{~cd}$ & $36.16 \mathrm{~cd}$ & $96.94 \mathrm{bcd}$ & $38.05 \mathrm{de}$ & $85.24 \mathrm{a}$ \\
\hline & 100 & $77.10 \mathrm{a}$ & $12.60 \mathrm{a}$ & $89.67 \mathrm{a}$ & $33.11 \mathrm{ef}$ & $89.69 \mathrm{e}$ & $37.22 \mathrm{e}$ & $85.97 \mathrm{a}$ \\
\hline \multirow{3}{*}{ Drill on ridge } & 60 & $53.96 \mathrm{~d}$ & $9.12 \mathrm{bc}$ & $63.08 \mathrm{e}$ & $45.85 \mathrm{a}$ & $105.14 \mathrm{a}$ & 43.88ab & $85.54 \mathrm{a}$ \\
\hline & 80 & $72.15 \mathrm{ab}$ & $11.20 \mathrm{ab}$ & $83.35 \mathrm{bc}$ & $40.97 b$ & 104.18ab & $39.74 \mathrm{cde}$ & $86.55 \mathrm{a}$ \\
\hline & 100 & $77.25 \mathrm{a}$ & $12.99 \mathrm{a}$ & $90.24 \mathrm{a}$ & $34.82 \mathrm{de}$ & $90.24 \mathrm{de}$ & 38.76de & $85.61 \mathrm{a}$ \\
\hline \multirow{3}{*}{ Drill on bed } & 60 & $53.17 \mathrm{~d}$ & $8.57 \mathrm{c}$ & $61.74 \mathrm{e}$ & $46.89 a$ & $102.89 \mathrm{abc}$ & $45.97 \mathrm{a}$ & $86.10 \mathrm{a}$ \\
\hline & 80 & $72.80 \mathrm{ab}$ & $11.92 \mathrm{a}$ & $84.72 \mathrm{ab}$ & $45.13 \mathrm{a}$ & $105.91 \mathrm{a}$ & $42.55 b c$ & $85.92 \mathrm{a}$ \\
\hline & 100 & $73.75 \mathrm{a}$ & $12.60 \mathrm{a}$ & $86.35 \mathrm{ab}$ & $35.49 \mathrm{~cd}$ & $86.35 \mathrm{e}$ & $41,31 \mathrm{bcd}$ & $85.42 \mathrm{a}$ \\
\hline
\end{tabular}

NUE $=$ Nitrogen use efficiency

$\mathrm{NPE}=$ Nitrogen physiological efficiency

$\mathrm{NRE}=$ nitrogen recovery efficiency

$\mathrm{NHI}=$ Nitrogen harvest index

\section{References}

Agapie, A.L., Parsan, P. and Gorinoiu, G. (2016) The fertilization - the basis of production and quality of winter wheat. Res. J. of Agric. Sci. 48(4), $186-189$.

AOAC. (1995) "Official Methods of Analysis" of the Association of Official Analytical Chemists. Washington, DC, 2004.

Black, C.A. (1965) "Methods of Soil Analysis. Part 1. Physical Mineralogical Properties Including Statistics of Measurement and Sampling". Am. Soc. Agron. Inc. Pub. Wisconsing, U.S.A.

Central Lab. for Agric. Climate (CLAC) (2015) Agric. Res. Centre, Ministry of Agric. and Land Reclamation, Egypt.

Dawson, J.C., Huggins, D.R. and Jones, S.S. (2008) Characterizing nitrogen use efficiency in natural and agricultural ecosystems to improve the performance of cereal crops in low-input and organic agricultural systems. Field Crop Res. 107, 89-101.

El-Habbal, M.S., Hassan, R.K., Sharshar, M.S. and
Noureldin, Gehan A. (2008) Effect of some fertilization sources on yield, yield components and nitrogen partitioning efficiency of some wheat genotypes under sandy soil conditions. Polletin Fac. Agric. Ain Shams Univ. 20.

El-Hadidi, E.M., Ibrahim, M.M., Abdel-hafez, S.A. and Eid, Mona S.M. (2015) Effect of deficit irrigation and raised bed on wheat yield, water productivity and water saving in north Nile Delta. J. Soil Sci. Agric. Eng., Mansoura Univ. 6 (7), 845 - 862.

Fenech, J. and Papy, F. (1977) Conditions needed successful emergence under a Mediterranean climate. The case of non-irrigated cereal crops in $\mathrm{N}$ Morocco. Ann. Agron. 78, 599-635.

Galichenko, I.I (1994) Which sowing method is best for winter crops. Zemledelie, 23-24.

Haile1, D., Nigussie, D. and Ayana, A. (2012) Nitrogen use efficiency of bread wheat: Effects of nitrogen rate and time of application. J. Soil Sci. Plant Nutr. 12(3), 389-409.

Hobbs, P.R., Singh, Y., Giri, G.S., Lauren, J.G. and Duxbury, J.M. (2000) Direct seeding and reduced 
tillage options in the rice-wheat systems of the IndoGangetic plains of South Asia. IRRI Workshop, Bangkok, Thailand, pp. 25-26.

Jackson, M.L. (1967) "Soil Chemical Analysis". Prentice Hall, Inc., Englewood Cliffs., N.J., U.S.A.

Kilic, H. (2010) The effect of planting methods on yield and yield components of irrigated spring durum wheat varieties. Sci Res. Essays, 5 (20), 3063-3069.

Moll, R.H., Kamprath, E.J. and Jackson, W.A. (1982) Analysis and interpretation of factors which contribute to efficiency of nitrogen utilization. Agron. J. 74, 562-564.

Mollah, M.I.U., Bhuiya, M.S.U., Hossain, M.S. and Hossain, S.M.A. (2015) Growth of wheat (Triticum aestivum L.) under raised bed planting method in rice-wheat cropping system Bangladesh. Rice J. 19(2), 47-56

SAS. (2003) Statistical Analysis System. Academic Computing Offer Ver. 9.1.3. Portable, NC, USA.
Deconvoluting nitrogen use efficiency in wheat: A simulation study. Eur. J. Agron. 26, 283-294.

Singh, G., Singh, O.P., Yadava, R.A., Singh, R.S. and Singh, B.B. (1994) Effect of seeding methods, seed rates and fertility levels on yield and economics of late sown wheat after rice in flood prone area .Ann. Agric. Res. 15, 448-451.

Singh, R.A. and Singh, R.G. (1992) Response of various methods on yield of wheat HUW 234. Agric. Sci. Digest Kernal, 12, 217-218.

Tahir, I.S., Nakata, N. and Yamaguchi, T. (2005) Response of three wheat genotypes to high soil temperature during grain filling. Plant Produ. Sci. 8(2), 192-198.

Timsina, J., Singh, U., Badaruddin, M., Meisner, C.M. and Amin, M.R. (2001) Cultivar, nitrogen and water effects on productivity and nitrogen use efficiency and balance for rice-wheat sequences of Bangladesh. Field Crop Res. 72, 143-161. 